\title{
PROMOTION HEALTH - EVALUATION OF THE LOCUS OF CONTROL OVER HEALTH
}

\author{
Mária Novysedláková 1 , Marta Kozáková ${ }^{2}$, Zuzana Hudáková ${ }^{3}$, Lada Cetlová ${ }^{4}$
}

\begin{abstract}
Health is a basic prerequisite for the existence and operation of values. Health care enables people to protect or restore health throughout their lives, from birth to death, in accordance with applicable legislation.

This paper aims to identify the importance of assessing a locus of control over health using the scale measuring tool, Multidimensional Health Locus of Control (MHCL). In total, 100 respondents participated in the survey, with an average age of 42 years. Statistical analyses were performed using Statistica, version 2007, with significance level of 0.05 .

Correlations of MHLC and attitudes toward preventive actions showed statistically significant results with readiness to quit smoking. People with high IHLC scores were more willing to stop smoking, change their diet, and reduce body weight. Our assumption in this research was that individuals who believed in internal control of health had a more positive effect regarding preventive actions.
\end{abstract}

UDC Classification: 159.9, 316.6, 316.4 DOI: http://dx.doi.org/10.12955/cbup.v4.832

Keywords: health promotion, health behavior, smoking, obesity, disease.

\section{Introduction}

Health support is based on scientific knowledge that the health of each individual is the result of the interaction of all aspects of his or her being and relationship to the outside world. Health promotion includes activities that an individual realizes to fully enjoy their life (Bastable, 2008). Healthy lifestyle is an activity with the aim to understand the health status and to maintain an optimal state of health. Rovný (2014) states that health promotion is the process enabling people to provide control of their health, that involve activities designed to improve physical well-being. Primary prevention is defined by Rovny (2014) as activities that are aimed at reducing the incidence of specific disease. In this case, where health promotion is evaluated, such a behavior pursues preservation of the initial state, i.e., it is a certain goal; whereas primary prevention involves understood activities, i.e., preventing an outcome (Dunkley, 2000). The ability to understand the behavior of the individual, to forecast this, and control and to change health-related behavior is problematic. A group of cognitive and social psychologists studied several psychological issues affecting health to identify the factors that affect compliance or non-compliance of a person. Health and human behavior cannot be separated. According to the estimation of the Centre for Disease Prevention, at least half of premature deaths are related to the behavior of individuals.

\section{Purpose of Study}

The aim of this study is to assess the degree of responsibility a person has for their own health, based on a selected group of respondents. We assumed that the attitude towards preventive actions for the benefit of one's own health relates to the conviction of an individual's responsibility towards health (internal locus of the control).

\section{Methods}

Multidimensional health locus of control scale (MHLC; Wallston \& Wallston, 1978) was used in the quantitative questionnaire survey. The scale range was divided into three subscales, each containing six items. Items were evaluated by the level of agreement with the statement of the 6-point Likert scale. The instrument focused on the level of control placement in relation to three areas: the internal locus of control where an individual believes he or she is responsible for their own health alone (scale items $1,6,8,12,13$, and 17); health control locus as coincidence where an individual believes that

\footnotetext{
${ }^{1}$ Mária Novysedláková, Faculty of Public Health, Catholic University in Ruzomberok, Slovakia, maria.novysedlakova@ku.sk

2 Marta Kozáková, Faculty of Public Health, Catholic University in Ruzomberok, Slovakia

${ }^{3}$ Zuzana Hudáková, Faculty of Public Health, Catholic University in Ruzomberok, Slovakia and Department of Health

Studies, College of Polytechnics in Jihlava, Czech Republic

${ }^{4}$ Lada Cetlová, Department of Health Studies, College of Polytechnics in Jihlava, Czech Republic
} 
health and disease are a matter of luck, fate, or absolute power (scale items 2, 4, 9, 11, 15, and 16); health control locus of 'powerful others' where the level of conviction relates to the extent health determined by a doctor, nurse, family, or friends (scale items 3, 5, 7, 10,14, and 18). Totals of the subscales ranged from $6-36$. Higher scores meant higher levels of control locus. Cronbach alpha was in the range of 0.67 to 0.77 .

Statistical data processing was carried out in MS Excel 2007 and Statistica software, version 2007. The statistical tests were Student's t-test, Mann-Whitney test, Pearson correlation coefficient, and a chi-square test at a significance level of $\alpha=0.05$.

The research sample consisted of adults who were either taking part in preventive health examinations or visiting a Health Centre during the observed period. from October 2013 to February 2014. In obtaining the research sample, we randomly chose subjects. Basic data for characterizing the research set were: age, sex, BMI body mass index, diseases in the family, and personal case history. The survey was conducted at general practitioners and in the client's area of the Centre of Health and Healthy Lifestyle. One hundred respondents took part in the research (return was 100\%), including 48 males and 52 females. The average age of respondents was 41.62 years (minimum 18 and maximum $62 \pm 0.8$ years).

\section{Results}

The evaluation in the area of internal locus of health control (IHLC) showed only one respondent with the lowest score (up to 12 points). There were 25 respondents in the range of moderate disagreement with the internal control of health (13-18 points). The most frequent responses were from the middle range (19-24 points), which was approximately the neutral position, and 29 respondents expressed mild approval. Only five respondents markedly agreed with the scale of items of internal health locus (31-36 points), as shown in Table 1.

Table 1: Internal health locus of control scale

\begin{tabular}{|l|l|l|l|l|}
\hline Score & $\begin{array}{l}\text { Absolute } \\
\text { frequency } \\
(\mathbf{N})\end{array}$ & $\begin{array}{l}\text { Cumulative } \\
\text { frequency }\end{array}$ & $\begin{array}{l}\text { Relative } \\
\text { Frequency } \\
(\%)\end{array}$ & $\begin{array}{l}\text { Cumulative } \\
\text { relative frequency }\end{array}$ \\
\hline $6-12$ & 1 & 1 & 0.01 & 0.01 \\
\hline $13-18$ & 25 & 26 & 0.25 & 0.26 \\
\hline $19-24$ & 40 & 66 & 0.40 & 0.66 \\
\hline $25-30$ & 29 & 95 & 0,29 & 0.95 \\
\hline $31-36$ & 5 & 100 & 0.05 & 1.00 \\
\hline Total & 100 & & 1.00 & \\
\hline Source: Kozáková \& Novysedláková (2014)
\end{tabular}

The average score from evaluation of the IHLC subscale in the selected file was 22.23. Transforming the file into a range of 0 to 100 would result in the average evaluation score of 54.30. Notably, the mean value was in the middle of the possible score range. Median and mode values were both 21, and slightly lower than the average. Standard deviation was 5.28, with the majority of scores in the range of $22.23 \pm 5.28$.

The final score of the locus of control of health as a coincidence or chance (CHLC) subscale are presented in Table 2.

For CHLC, the lowest score (up to 12 points) was reported by seven respondents. In total, 24 respondents were in the range of mild disapproval (13-18 points) with 'health as a chance'. Even at this subscale the most frequent answers were from the middle range (19-24 points), which expressed roughly the neutral position. There were 43 respondents in the mid-range. Mild approval was obtained from 26 respondents. Resolute acceptance of the attitude that health was mainly the result of chance was expressed by none of the respondents. 
Table 2: Chance health locus of control scale

\begin{tabular}{|l|l|l|l|l|}
\hline Score & $\begin{array}{l}\text { Absolute frequency } \\
(\mathbf{N})\end{array}$ & $\begin{array}{l}\text { Cumulative } \\
\text { frequency }\end{array}$ & $\begin{array}{l}\text { Relative Frequency } \\
(\boldsymbol{\%})\end{array}$ & $\begin{array}{l}\text { Cumulative relative } \\
\text { frequency }\end{array}$ \\
\hline $6-12$ & 7 & 7 & 0.07 & 0.07 \\
\hline $13-18$ & 24 & 31 & 0.24 & 0.31 \\
\hline $19-24$ & 43 & 74 & 0.43 & 0.74 \\
\hline $25-30$ & 26 & 100 & 0.26 & 1.00 \\
\hline $31-36$ & 0 & 100 & 0.00 & 1.00 \\
\hline Total & 100 & 1.00 & \\
\hline \multicolumn{2}{|l}{ Source: Kozáková \& Novysedláková,2014 } \\
\end{tabular}

Average evaluation score of this CHLC subscale was 20.96 in the selected file. Compared with the previous subscale, this assessment was somewhat lower. Transforming this into a $0-100$ scale would result in an average score of 49.80. It became increasingly clear that the mean value was approximately in the middle of the possible range of scores, the median and modal values were 22 . Most scores were in the range $20.96 \pm 4.83$.

The final score of the locus of health control of 'powerful others' (PHLC) subscale is indicated in Table 3. None of the items were reversed, and thus the total score was calculated by summing the responses for each item.

Table 3: Powerful others health locus of control scale

\begin{tabular}{|l|l|l|l|l|}
\hline Score & $\begin{array}{l}\text { Absolute frequency } \\
(\mathbf{N})\end{array}$ & $\begin{array}{l}\text { Cumulative } \\
\text { frequency }\end{array}$ & $\begin{array}{l}\text { Relative Frequency } \\
(\%)\end{array}$ & $\begin{array}{l}\text { Cumulative relative } \\
\text { frequency }\end{array}$ \\
\hline $6-12$ & 5 & 5 & 0.05 & 0.05 \\
\hline $13-18$ & 27 & 32 & 0.27 & 0.32 \\
\hline $19-24$ & 41 & 73 & 0.41 & 0.73 \\
\hline $25-30$ & 25 & 98 & 0.25 & 0.98 \\
\hline $31-36$ & 2 & 100 & 0.02 & 1.00 \\
\hline Total & 100 & 1.00 & \\
\hline \multicolumn{2}{|l}{ Source: Kozáková \& Novysedláková (2014) } \\
\hline
\end{tabular}

For PHLC, the lowest score (up to 12 points) was reported by five respondents. In total, 27 respondents moderately disagreed (13-18 points) with the localization of health in others. Also in this subscale, the most common responses (41) were from the middle range (19-24 points), which expressed roughly neutral attitude. Mild disapproval was expressed by 25 respondents. Two respondents significantly agreed (31-36 points) with the items of this range.

Average evaluation of this PHLC subscale was 21.08 in the selected file. Transforming this into a 0 100 scale would result in the average score of 50.3. From this outcome, it is clear that the mean value is approximately in the middle of the possible range of scores. The median and the mode were both equal to the value 22 , which is also placed at about the center of the range of possible scores. Most scores were in the range $21.08 \pm 5.40$.

The assessment scores of individual subscales only slightly differed and all mean values were in the middle of the score range. Thus, we can conclude that the majority of respondents were inclined towards the less decisive assessment of individual subscales (Table 4). 
Table 4: Correlation of IHLC and attitude to the preventive behavior

\begin{tabular}{|l|l|l|}
\hline \multirow{2}{*}{ Position of respondents } & \multicolumn{2}{|c|}{ Internal health localization of control (IHLC) } \\
\cline { 2 - 3 } & correlation coefficient & p-value \\
\hline Efforts to strengthen health & -0.132 & 0.093 \\
\hline Change way of eating & 0.009 & 0.465 \\
\hline Reduce alcohol consumption & 0.034 & 0.412 \\
\hline Reduce weight & -0.127 & 0.122 \\
\hline Quit/stop smoking & 0.329 & 0.021 \\
\hline Eliminate stress & -0.049 & 0.328 \\
\hline More rest & 0.113 & 0.134 \\
\hline Source: Kozáková \& Novysedláková (2014) \\
\hline
\end{tabular}

Each line of the table shows the correlation coefficients between the IHLC scores and items shown in the table line. Almost all correlation coefficients were close to zero with mean trivial dependence. Only one coefficient was statistically significant. The correlation of IHLC score and willingness to quit smoking was equal to 0.329 and the p-value in the test of significance of the correlation coefficient was equal to 0.021 . The respondents with higher scores in IHLC were more willing to quit smoking. More than a third of respondents $(n=37)$ confessed that they currently smoke, two respondents were trying to quit smoking, and 22 respondents had been smokers in the past. Active smokers partook of an average 16.64 cigarettes a day. The most common duration time of being an active smoker was 6-10 years. In total, 27 respondents occasionally drink 'hard' alcohol and 21 respondents drink alcohol regularly. People who drink hard liquor regularly, would consume an average of 2.95 glasses of 0.05 -liter volume, weekly. The willingness of those who had BMI above 25 $\mathrm{kg} \mathrm{m}^{-2}$ to change their diet was, on average, positive, with the average value of 3.68 only slightly higher than for the entire survey sample. Willingness to adjust their weight, in respondents with BMI above $25 \mathrm{~kg} \mathrm{~m}^{-2}$, was significantly higher at 3.95 , compared to the whole research group, which had an average assessment of 3.31 .

Table 5: Factors impeding health promotion

\begin{tabular}{|l|l|l|l|l|l|}
\hline Factors & Frequency & Average & Modus & $\begin{array}{l}\text { Frequency } \\
\text { mode }\end{array}$ & $\begin{array}{l}\text { Standard } \\
\text { deviation }\end{array}$ \\
\hline Overcoming habits & 100 & 3.30 & $\begin{array}{l}1-\text { not } \\
\text { at all }\end{array}$ & 24 & 1.76 \\
\hline Lack of motivation & 100 & 3.27 & $\begin{array}{l}3 \text { very } \\
\text { few }\end{array}$ & 26 & 1.54 \\
\hline Finance & 100 & 2.99 & $\begin{array}{l}3 \text { very } \\
\text { few }\end{array}$ & 23 & 1.46 \\
\hline Lack of knowledge & 100 & 2.66 & $\begin{array}{l}1-\text { not } \\
\text { at all }\end{array}$ & 34 & 1.54 \\
\hline Environmental influences & 100 & 2.36 & $\begin{array}{l}1-\text { not } \\
\text { at all }\end{array}$ & 38 & 1.29 \\
\hline Source: Kozáková \& Novysedláková (2014) &
\end{tabular}

Overcoming habits or 'bad' habits were considered by respondents the strongest factor that prevents good health maintenance (Table 5). Average assessment scores reached 3.30 points, which in general reflected slightly positive support. The second most common reason preventing changes for health 
improvement was the lack of motivation, with an average value of 3.27 points, which in general indicated this factor as adverse. In general, the respondents showed neutral, or indecisive attitudes towards improving their health.

\section{Discussion}

The conception of control locus has application in relation to health, for example, as a predictor of the educational intervention success, tracking, and maintaining healthy behaviors or compliance with the treatment (Steptoe \& Wardle, 2001). Of the client's attitudes towards health care, those important were mainly concerns affecting their own medical conditions. People who can provide internal control are more likely to undertake initiative in their own health care. They gain more knowledge and information about it, are more willing to follow the recommended advice, and act for the benefit of their health by preventive activities. The second group of people believe their health is influenced by external factors and they cannot markedly control their own health. People who are controlled from outside need help towards following more internal motives, otherwise any attempts to change their practices will be unsuccessful (Kozierová, Erbová, \& Olivierová, 2004).

Our assumption in this research was that individuals who believe in internal control of health have more positive impact on preventive actions. For verification, we compared the scores of internal health locus of control (IHLC) with items of a questionnaire related to attitudes towards preventive actions. The average assessment score in the IHLC subscale for the selected sample was 22.23 , for the PHLC subscale 21.08, and for the CHLC subscale 22.23. The most frequent positive responses were in the middle interval of 19 to 24 points, which was approximately the neutral position. Correlations of IHLC and attitudes towards preventive actions showed statistically significance for IHLC and the item: readiness to quit smoking. People with high IHLC scores were more willing to stop smoking, change their diet, and reduce body weight. Based on the research results, it appears important to assess the strength of health awareness, but, also to note that individuals with internal locus of health (IHLC) infrequently make adequate effort for preventive activities. Overcoming habits or 'bad' habits were considered by respondents the strongest factor that prevents or inhibits 'good' health maintenance.

Scores for the IHLC scale were positively correlated with life satisfaction, the desire to control one's own health care, obtaining information, and compliance with health recommendations, and negatively correlated with physical symptoms. The PHLC scores were positively correlated with investigating information on compliance with recommended treatment and negatively correlated with the desire for control over health care provision. The CHLC scores had a positive correlation with the level of depression and physical symptoms, and ne gatively correlated with the desire for control of health care provision (Wallston, 2005). Health status is a result of the amount of biological and social impact on a person (Hudáková \& Dvořáková, 2014). In general terms, risk behavior is perceived as behavior, the outcome of which is not clear, and this requires balancing the possible negative consequences (losses) with the positive effects (gains). The risk forms of behavior are classified as all forms of drug behavior, violation of social norms, promiscuity, and others. The opposite of risk factors are protective factors that imply preventive protection of humans against the influence of negative effects from the internal (physical and mental) and external (e.g., social, environmental) settings to prevent health hazards, undesirable behavior, or disease outbreaks (Jurkovičová, 2005). Our study group especially involved smokers willing to change their habits. Furthermore, the unhealthy habits and habits observed overall in this study are also the most frequently cited as a barrier to change in literature (Steptoe \& Wardle, 2001; Bastable, 2008).

Medical fields, deal with prevention, diagnostics, and treatment of diseases. The task of health care requires an interdisciplinary approach. Pedagogy helps to master educational practices in health support, preservation of health, or restoring health (Novysedláková \& Višňovská, 2009). The health workers have independent competence, enabling them to perform activities, promoting health competencies for creating and forming a conscious and responsible attitude to health. These activities include promoting health, process of education, and preventive actions.

\section{Conclusion}

In this paper, we assessed the assumption that the individual who believes in internal control of health has positive impact on their preventive actions. In the examined group, correlation between willingness to improve one's own health and the internal locus of health control was not established, 
apart from where Internal locus of the health control (IHLC) coincided with a willingness to quit smoking $(\mathrm{p}=0.021)$. To promote health, workers in this field should focus, as previously mentioned, on identifying an individual's attitude towards health care and the extent to which people believe they can influence their own health by their actions. The authors believe that education presents an important role in solving problems related to achieving an effective compliance in respondents.

\section{References}

Bastable, S. B. (2008). Nurse as Educator - principles of teaching and learning for nursing practice. Sudbury, Mass: Jones and Bartlett.

Dunkley, J. (2000). Health promotion in midwifery practice: a resource for health professionals. Bailliere Tindall.

Hudáková, Z., \& Dvořáková, V. (2014). Životný štýl a výchova k zdraviu ako celoživotný proces. Zborník z medzinárodnej konferencie. Ružomberok: Verbum; 2014. s.182-191. [Lifestyle and health education as a lifelong process. The Proceedings of the International Conference. Ruzomberok: Verbum; 2014. p. 182-191.]

Kozáková, M., \& Novysedláková, M. (2014). Health protection as a basic mission of nursing. Ružomberok: Catholic University in Ruzomberok, Faculty of Public Health, 2014, p. 79.

Kozierová, B., Erbová, G., \& Olivierová, R. (2004.) Ošetrovatel’stvo 1. Martin: Osveta, 836 s. [Martin Nursing: education, p. 836].

Jurkovičová, J. (2005). Vieme zdravo žit? Bratislava: LF UK. [Can we live in a healthy lifestyle? Bratislava: Faculty of Medicine.]

Novysedláková, M., \& Višňovská, D. (2009). Edukácia v ošetrovatel'stve. Zborník referátov z medzinárodnej vedeckej konferencie. Ružomberok: PF KU, s. 344 - 349. [Education in nursing. Research in the Mirror of Time: Proceedings of the international conference. Ruzomberok: KU PF, p. 344 - 349.]

Rovný, I. (2014). Vybrané kapitoly z verejného zdravotníctva II. Banská Bystrica: Vydavatel'stvo PRO; 2014. [Selected chapters from Public Health II. Banská Bystrica: Publishing PRO.]

Steptoe, A., \& Wardle, J. (2001). Locus of control and health behaviour revisited: a multivariate analysis of young adults from 18 countries. Br J Psychol. 2001; 92 (4): 567-696.

Wallston, K. A., \& Wallston, B. S. (1978). DeVellis R. Development of the multidimenzional health locus of control (mhlc) scales. Health education monographs. 1978; 6 (2): 160-170.

Wallston, K. A. (2005). The validity of the multidimensional health locus of control scales. Journal of Health Psychology. 2005; 10 (5): 623-631. 